\title{
Agouti-Signaling Protein
}

National Cancer Institute

\section{Source}

National Cancer Institute. Agouti-Signaling Protein. NCI Thesaurus. Code C131343.

Agouti-signaling protein (132 aa, $\sim 15 \mathrm{kDa}$ ) is encoded by the human ASIP gene. This protein is involved in the inhibition of melanin synthesis and the promotion of pheomelanin synthesis. 